\title{
SMALL TALK AMONG THE INDONESIANS IN THREE DIFFERENT COUNTRIES: AMERICA, INDONESIA, PHILIPPINES
}

\author{
Caroline Victorine Katemba \\ English Department, Faculty of Education, \\ Universitas Advent Indonesia, Email : linakatemba@gmail.com
}

\begin{abstract}
This study explores the "Small Talk" Among the Indonesians in three countries. It aims to determine the topics that make up a small talk among the Indonesians in the motherland/homeland, USA (New Jersey, LA, Washington D.C), and the Philippines (Manila).This study sought to answer the following questions: (a) What particular topics of conversation shared by the Indonesians upon meeting for the first time? (b). Are Indonesians who stay in the motherland/homeland and those who are in the Philippines and those who migrated to the USA shared the same topics? (c). What changes of conversational topic has taken place?
\end{abstract}

Key Words: small talk, Indonesian culture, the Indonesians

\section{Background of the Study}

In the 'First International Conference and $40^{\text {th }}$ Annual Convention on Language Education' at Manila Midtown Hotel, April 25-27, 2001 Dr. Francisco Sionil Jose (National Artist for Literature) was one of the Guest Speaker. In the introduction of his speech he said "Long-long time ago. You were not born yet. I attended a seminar in Indonesia, by the belated first Indonesian president. President Ir. Sukarno. He delivered his speech for six hours non-stop without a text". Indonesians are great talkers (Thomas Oey, 1993).

As I would say that, We Indonesians love to talk. We are also an instinctively inquisitive people, and will often approach you on trains, planes, busses, etc to strike up a conversation. As expressed in the common greetings Mau ke mana? And Sudah makan belum? Indonesian always seem to want to know everything about you: where you are going, what you are doing, who you are, whether you have eaten or bathed yet, etc. Just as in English greetings " How are you?", "Hi” or "How do 
you do?" when meeting someone. These greetings do not require a specific answer, but are simply another way of saying hello.

Once the greetings are over, however, visitors will frequently find themselves barrage with a series of more specific questions, including many that seem to concern very personal and intimate matters, such as personal or family background, marital status, occupational, and so forth. These will come up again and again until you can almost predict what question is coming next, and are probably quite tired of this whole "interview" process.

Try not to be sarcastic or angered by this. Understand that your "interviewers" are simply trying to be friendly, and are using such topics to make small talk, much as Westerners would discuss the weather or sports. In Indonesia, such information is not considered personal at all, it is simply a part of one's identity-like your name, nationality and address. If you do not wish to answer, it is perfectly acceptable to be equivocating or to joke around. Most Indonesians will never press you for an answer. On the other hand, you can use this as an opportunity to practice your Indonesian, and by turning the questions around you can also learn something about the people you meet.

\section{Statement of the Problems}

This study aims to determine the topics that make up a small talk among the Indonesians in the three different countries:

1. Indonesia (motherland/homeland),

2. USA :

a. Los Angeles,

b. New Jersey, and

c. Washington D.C.

3. Philippines

Specifically, this study sought to answer the following questions:

4. What particular/common topics of conversation shared by the Indonesians upon meeting for the first time?

5. Are Indonesians who stay in the motherland/ homeland and those who are in the Philippines and those who migrated to the USA shared the same topics?

6. What changes of conversational topic has taken place? 


\section{Scope and Delimitation of the Study}

The study focused on the topics that make up a small talk among the Indonesian upon meeting for the first time. It involved three countries: Indonesia, USA, and the Philippines.

\section{Definition of Terms}

The following terms are operationally and conceptually defined for clarity.

Anomie. It refers to a feeling of homelessness, where one feels neither bound firmly to one's native culture nor fully adapted to the second culture.

Self identity. In this study, self identity refers to his/her status in the Community.

Prestige. It refers to status, position, or rank in the community.

Motherland/ homeland: refer to the Indonesians who stay in Indonesia.

Occupation. In this study, it refers to their present work or previous work in the the country (Indonesia)

Self-perception. Is an individual's overall comprehension of self, including selfconcept, self-esteem, and self-ideal. It also refers to how you perceive yourself- your own thoughts, beliefs, and feelings about yourself.

Self-ideal - a description of how an individual perceives he or she should or would like to be.

Self-esteem. Refers to how you feel about yourself, to positive or negative self-evaluations. It is and overall feeling, in transactional analysis terms, of being "O.K" or "not O.K" (Haris,1976)

\section{Review of Related Literature and Conceptual Framework}

\section{Communication:}


Communication is a systemic process in which individuals interact with and through symbols to create and interpret meanings. The important idea in this definition is: process, systemic, symbols and meanings.

1. Process. Communication is a process, which means it is ongoing and always in motion. The fact that communication is a process means it is always in motion, moving ever forward, and changing continuously. We cannot freeze communication at any one moment.

2. Systemic. Communication is also systemic, which means that it involves a group of interrelated parts that affect one another. In family communication, for instance, each member of the family is part of the system. A lingering kiss might be an appropriate way to communicate affection in a private setting, but the "same" nonverbal behavior would raise eyebrows in an office. To interpret communication, we have to consider the entire system in which it takes place.

3. Symbols, which are abstract, arbitrary, and ambiguous representations of other things. Symbols include all of language and many nonverbal behaviors, as well as art and music. Anything that abstractly signifies something else can be a symbol.

Meanings, which are the heart of communication. We talk with others to clarify our own thoughts, decide how to interpret nonverbal behaviors, and put labels on feelings and hopes to give them reality. In all of these ways, we actively construct meaning by working with symbols. ( wood 1997).

\section{Values of Communication}

We spend more time communicating than doing anything else. We talk, listen, have dialogues with ourselves, watch television and listen to radio, participate in group discussions, browse the World Wide Web, interview or are interviewed, send electronic mail messages, and so forth. From birth to death, we communicate to meet personal, professional, relationship, and social goals.

\section{PERSONAL Impact}

George Herbert Mead (1934), said humans are talked into humanity. He meant that we gain personal identity through communicating with others.

Communication with others not only affects our sense of identity, but also directly influences our physical well-being. People who lack close friends have greater levels of anxiety and depression than people who are close to others( Hojat, 1982; Jones \& Moore, 1989). Heart disease is also more common among people who lack strong interpersonal communication, reports that people in disturbed 
relationships tend to have low self-esteem, headaches, alcoholism, cancer, sleep disorders, and other physical problems. Clearly, healthy interaction with others is important to our physical and mental health. (Wood,1997).

\section{Relationship Impact}

Communication also critically affects our relationships. We build connections with others by revealing our private identities, remembering shared history, planning a future, and working out problems and tensions. Marriage counselors have long emphasiced the importance of communication for healthy, enduring relationships (Beck, 1988; Gottman \& Carrere, 1994; Scarf, 1987). They points out that troubles and problems are not the primary reason some marriages fail, since those are common to all relationships.

Communication is important as more than a way to solve problems or make personal disclosures. Steve Duck (1994b, p.52), who studies personal relationships, says that "talk is the essence of relational maintenance." Through small talk, gossip about mutual acquaintances, nonverbal exchanges, and discussions of clothes and other mundane topics, partners embody their relationship. For this reason, couples involved in long-distance romances say the biggest problems are missing the nonverbal communication that occurs in face-to-face interaction and not being able to share small talk (Gerstel \& Gross, 1985).

\section{Cultural Impact}

Communication skills are also important for the health of our society. To be effective, citizens in a democracy have to be able to express ideas and to evaluate the ideas of others. Good communication skills are the essence of social life. Particularly as our culture becomes increasingly pluralistic, we must all learn to interact with people who differ form us and to learn form them in the process. This means we need to understand the different verbal and nonverbal communication styles that are learned in distinct communication cultures.

Communication, then, is important for personal, relationship, professional, and cultural reasons. Because communication is a cornerstone of human life (Wood,1997) 


\section{Communication and Culture}

Your culture directly shapes how you communicate, teaching you whether it's polite to interrupt, how much eye contact is appropriate, whether individuality is desirable, and whether argument and conflict are healthy.

Patterns of communication reflect cultural values and perspective. Consider, for example, that many Asian languages include numerous words to describe particular relationships: my grandmother's brother, my father's uncle, my youngest son, my oldest daughter. This linguistic focus reflects the cultural emphasis on family relationships (Ferrante, 1995). Therefore are fewer and less specific English words to describe kinship bonds, which reflects the lesser salience of familial relationships in Western culture.

Asian cultures also revere the elderly, and this too is reflected in language. "I will be 60 tomorrow" is an Asian saying that means I have enough years to deserve respect. In contrast, western cultures tend to prize youth and to have many positive words for youthfulness(young in spirit, fresh) and negative words for seniority (has been, old fogy, over the hill, outdated, old-fashioned).

In the process of leanring language, we learn our culture's values, beliefs, and norms. Then, as we use the language of our culture, we reflect its values, norms, and beliefs. Language also effects cultural views of personal identity. Western cutlrues tend to emphasize individuals, whereas many Eastern cultures palce greater emphasis on family and community than on individuals. (Wood,1997)

\section{CULTURE}

Culture is learned, acted out, transmitted, and preserved through communication. Communication - our ability to share our ideas and feelings-is the basis of all human contact.

Culture is a system of shared beliefs, values, customs, behaviors, and artifacts that the members of a society use to cope with their world and with one another, and that are transmitted from generation to generation through learning. This definition includes not only patterns of behavior but also patterns of thought (shared meanings that the members of a society attach to various phenomena, natural and intellectual, including religion and ideologies), artifacts (tools, pottery, houses, machines, works of art), and the culturally transmitted skills and techniques used to make the artifacts. (D.G. Bates, 1990). 


\section{Culture is Subject to Change}

Cultures are dynamic systems that do not exist in a vacuum, sot they are subject to change. Change through contact is another example of how communication and culture are alike. Communication is not static, but rather is dynamic and constantly changing . Cultures are also subject to fluctuations, seldom remaining constant. Although cultures change through several mechanisms, the three most common are innovation, diffusion and acculturation. (samovar et.al,1998. pp.45)

Innovation defined as the discovery of new practices, tools, or concepts that many members of the culture eventually accept and that may produce slight changes in social habits and behaviors(Nada,1994 in Samovar et.al)

Diffusion si the borrowing by one culture from another. Historically, diffusion has been part of cultural contact for as long as cultures have existed. S

Culture is Subject to change.

Cultures are dynamic systems that do not exist in a vacuum, so they are subject to change.

Change through contact is another example of how communication and culture are alike. Communication is not static, but rather is dynamic and constantly changing. Cultures are also subject to fluctuations, seldom remaining constant. Although cultures change through several mechanisms, the three most common are innovation, diffusion, and acculturation.

Innovation is usually defined as the discovery of new practices, tools, or concepts that many members of the culture eventually accept and that produce slight changes in social habits and behaviors (Nada,1994)For example television, the computer, and the women's rights movement are good examples of products and concepts that reshaped culture. The three examples cited, change occurs much faster, and there is more of it, in modern and technological cultures (Nada,1994)

-Diffusion, another mechanism of change, is the borrowing by one culture from another. Historically, diffusion has been part of cultural contact for as long as cultures have existed. 
. Because cultures want to endure, they usually adopt only those elements that are compatible with $t * r$ values and beliefs or that can be modified without causing major disruption (Samovar, et al,1998)

Acculturation, as a type of cultural change, "occurs when a society undergoes drastic culture change under the influence of a more dominant culture and society with which it has come in contact (Hoebel \& Frost). Usually acculturation is in response to extended and intensive firsthand contact between two or more previously autonomous cultures or co-cultures. This type of change is common to international immigrants, who for a variety of reasons find themselves in another culture. These people, as part of the acculturation process, need to cope with a considerable amount of cultural change. In most instances, they "begin to detect new patterns of thinking behavior and to structure a personality relevant to adaptation to the host society (Gudykunst, et al, 1992) As Bates and Plog point out, "A society that gradually adopts the practices of another culture does not adopt every behavior or belief of that culture (pp. 437)

\section{Conceptual Framework}

The conceptual framework of this study was guided by different theories previously mentioned. The conceptual framework of this study illustrated in Fig.1 shows that the Indonesian in the USA (Los Angeles, New Jersey and Washington D.C), Philippines and Indonesia (homeland/motherland) were the subjects of the study. The figure shows that small talk among the Indonesians in three countries has a relationship to one another since they are all Indonesian which inhabit different locations. Since they are Indonesian, they must have inherit the Indonesian culture which belongs to the eastern/Asian culture. The Indonesians in the three countries of course inherit the Eastern Culture. Indonesians who are domicile in the state will have a direct counteract with the western culture in which might affect the topic of their communication of their small talk. 
Indonesians in the USA will have a slight change on the topic of their small talk since they are adapting the culture, the western culture that penetrates into their way of life/living. So, not only their topic of communication would be change or affected but also their culture might deviate from those who are in the homeland. Those who are in the Philippines might as well maintain/have the same topic since the Philippines is also belong to the eastern culture, which is similar to the Indonesian culture. There won't be much change.

Figure 1

\section{CONCEPTUAL FRAME WORK}

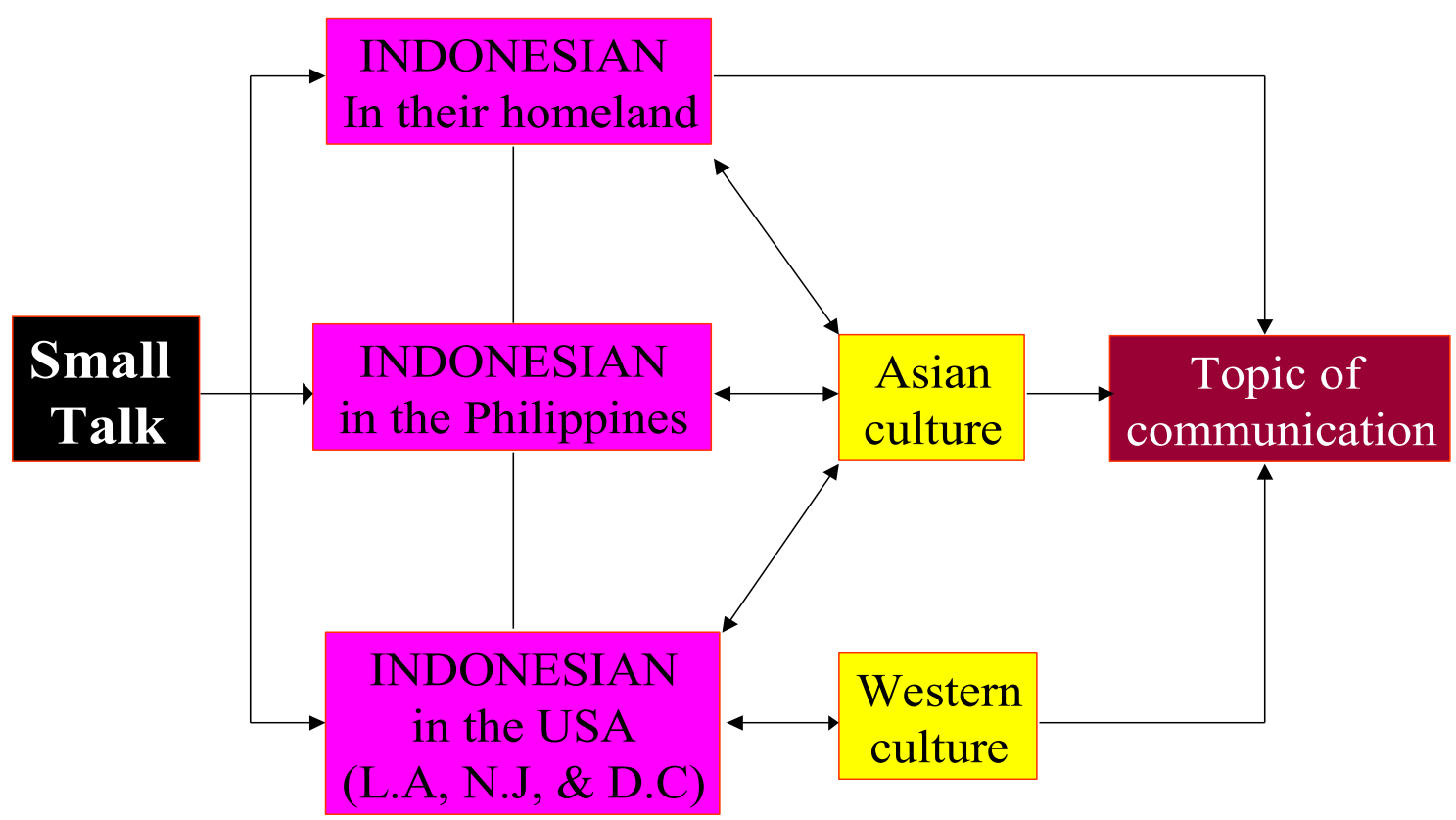

METHODOLOGY

\section{Research Method and Design}

The ethnographic and cultural analysis was used to determine the common or general topic used to make up a small talk. Cultural background play an important 
role in communication. It may shape up the topic and the way it is being communicated.

\section{Data Gathering and Procedure}

\section{Observation}

An observation was done by the researcher in the

1. airport, in the airplane, train station

2. celebration/ thanks giving, party

3. national independence day program - August 17 at the a. Indonesian Embassy in Washington D.C. b. Indonesian Embassy in the Philippines

4. church, Buddha temple, mosque, universities

5. malls, traditional markets, book stores, etc.

\section{Informants and Involvement}

Beside an observation done by the researcher, the researcher also was directly involved in the conversation with other Indonesian whom the researcher had met for the first time. Data was also secure from other informants in the homeland, Philippines and the USA.

\section{Electronic device}

a. Internet - chatting

b. email

\section{Research Locale}

This study was conducted in three different countries:

1. Indonesia

2. The United states of America and

3. The Philippines.

Indonesia has more than 13,700 island. It has a tropical climate and has two seasons, wet and dry. The researcher observed people from the east to the west of Indonesia. The east part include: The Celebes Island and through the west the Java Island, Bali Island and Sumatra Island. 


\section{Data Analysis, Interpretation and Conclusion}

Presented in this chapter are the data duly analyzed and interpreted to answer the problems of the present study. The presentation of data is divided into three main parts.

Part I discusses the particular/common topics of conversation are shared by the Indonesians upon meeting ofr the first time. Part II discusses the topics of conversation that initiate a small talk among the Indonesians in the USA and the Philippines. Part III. Sjows changes of topics that has taken place.

\section{Part I. What particular/common topics of conversation shared by the Indonesians upon meeting for the first time?}

The following topics are usually asked or talked about in a common conversation by the Indonesians in Indonesia

\section{Name and Nationality}

One of the first questions asked, following your name, will be about your nationality. Nama bapak/ibu siapa? Or Siapa nama bapak/ibu?

What is your name?

Nama saya Jonathan.

My name is Jonathan

\section{Nama saya Caroline.}

My name is Caroline.

\section{Bapak/ibu asal dari mana? Or Asalnya dari mana?}

What country are you from? /what province or village are you from?

\section{Saya dari Filipina.}

I am from the Philippines. 
Or Saya orang Filipina.

I am Filipino.

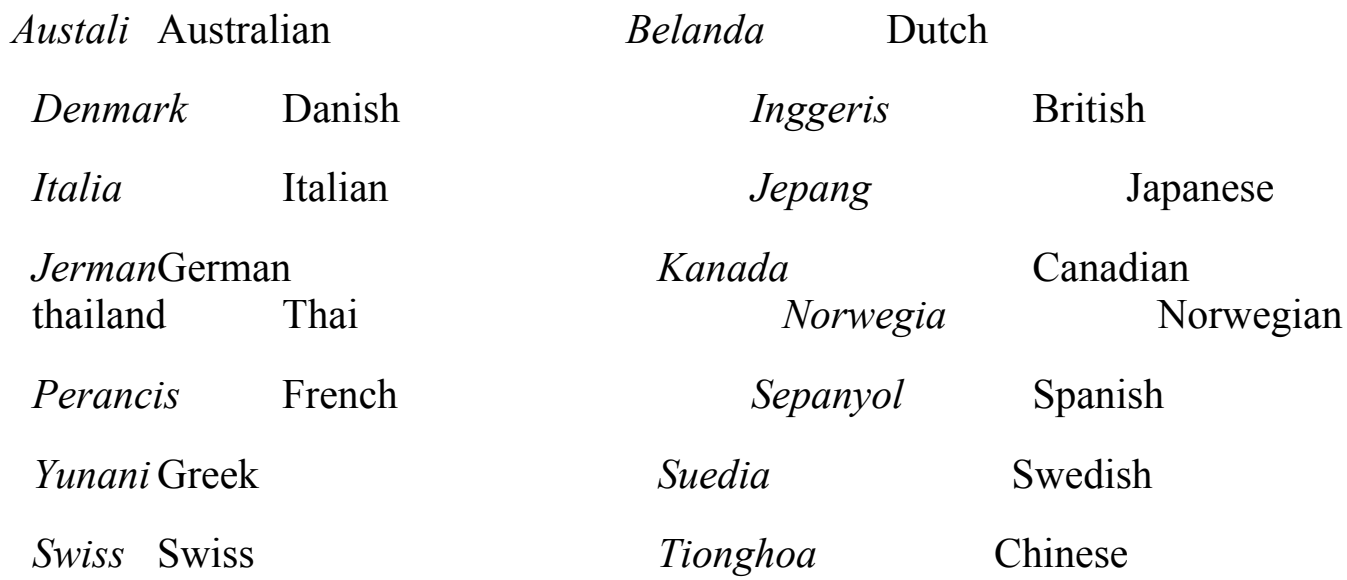

Selandia Baru- A new Zealander

AGE

The next thing most people want to know is your age.

Umur age berumur to be of the age, have the age.......

Tahun year(s) lahir to be born muda young tua old

Umur bapak/ibu berap(tahun)? How old are you

Umur saya tiga puluh enam. I am 36 (my age is 36).

Saya lahir tahun sembilan belas enam puluh lima. I was born in 1965.

In answering evasively, you may want to joke and say:

Saya sudah tua, mau pensiun. I am already old, ready to retire.

Saya masih muda. I am still young.

Saya masih anak-anak. I am still a child. 


\section{Family}

Next you will be asked about your family and marital status. Indonesians expect all adults over 25 to be married and all married couples to have children, and will be surprised if they find this is not the case. If you are over 25 and still single, and don't wish to pursue the matter further, you might consider just saying that you are married and have three children anyway(which is what the person asking expects you to say).

$$
\begin{aligned}
& \text { Ayah,bapak-father } \quad i b u \text {-mother isteri-wife suami-husband } \\
& \text { Perempuan - woman, female laki-laki-male, man } \\
& \text { kawin, nikah - to be married keluarga-family anak-child } \\
& \text { saudara - brother or sister (sibling) adik-younger sibling } \\
& \text { kakak-older sibling orang-person anakperempuan-daughter } \\
& \text { cucu-grandchild, grand niece or nephew orang tua-parent/old people }
\end{aligned}
$$

Bapak/ibu sudah kawin belum? Are you married yet/

Sudah /Belum. Already/Not yet

Masih terlalu muda. (I am) still too young.

Bapak/ibu punya berapa anak? How many children do you have?

Saya punya tiga anak. I have three children.

Satu laki-laki dan dua perempuan. One son and two daughters,

Tuan punya berapa saudara? How many brothers and sisters do you have? Saya punya tiga saudara. I have three siblings.

\section{Kakak laki-laki satu dan adik perempuan dua.}

One older brother and two younger sisters.

\section{Occupation}


Next will be questions concerning your job or profession. Most educated Indonesians carry a business card. They may offer you one and ask for yours. After even a brief conversation, many people will want to have your address. Usually they keep it for a remembrance. Indonesians are very happy to have foreign friends. Don't be surprise if you are invited to their house, and later to be introduced to their family and neighbors.

$\begin{array}{lcr}\text { Belajar- to study } & \text { perusahaan-company bekerja-to work } \\ \text { Kartu-card } & \text { kartu nama-name card } & \text { pensiun-retired } \\ \begin{array}{l}\text { Dosen-university lecturer } \\ \text { Pedagang-businessman }\end{array} & \begin{array}{c}\text { guru-teacher } \\ \text { pengarang-writer }\end{array} & \begin{array}{r}\text { manajer-manager } \\ \text { pendeta-minister }\end{array} \\ \text { Sekertaris-secretary } & \text { pelaut-sailor } & \text { Insinyur-engineer }\end{array}$

Mahasiswa-university student Dokter-doctor petani-farmer

Bapak/ibu bekerja di mana? Where do you work?

Saya bekerja di perusahaan.... I work at company....

Saya bekerja di kantor- I work in an office.

Saya pengangguran- I am unemployed/jobless

Ada kartu nama?- Do you have a name card?

Boleh saya minta satu? May I have one?

Ma'af, tidak ada. I'm sorry I don't have one.

\section{Religion}

It is common for Indonesians to ask about your religion. For most people in Indonesia, religion is not so much a question of personal beliefs as it is a reflection of one's ethnic or cultural identity. Indonesia recognizes only six official religions: Buddhism, Hinduism, Islam, Catholicism, Protestantism, and Advent, and Indonesians will expect most Westerners to be either Protestants or Catholics. Atheism is not officially recognized, and many Indonesians will not know what does 
this mean. To us, it is like not having a sname or a nationality. When in doubt, just say that you are "Kristen" or "Katolik."

$$
\begin{array}{ll}
\text { Agama-religion } & \text { gereja-church mesjid-mosque } \\
\text { Anggota-member } & \text { klenteng-china temple masuk- to enter, convert }
\end{array}
$$

Bapak/ibu agama apa? What religion are you?

Saya orang Hindu. I am Hindu.

Banyak orang Bali begitu. So are many Balinese.

Saya orang Advent. I am Seventh Day Adventist.

$$
\begin{aligned}
& \text { Islam - Muslim Katolik-Catholic Budha-Buddhist } \\
& \text { Yahudi - Jewish Kristen, Protestan - Christian, Protestant }
\end{aligned}
$$

Note: As a result of Dutch influence, Indonesians make a clear distinction between Protestant and Catholics, and have no general term to express "Christian." To say that one is Kristen in Indonesian means specifically that one is Protestant. Note also that in certain areas of Indonesia, where Islam is particularly strong, it may not be a good idea to say that you are Jewish, although in most places this will not create any problems.

\section{Part II. Are Indonesians who stay in the motherland/ homeland and those who migrated to the USA and other countries shared the same topics?}

No, Indonesians who stayed in the motherland/ homeland will always have the old common topics to begin their "Small Talk", however, the researcher found out that topics used to elicit a small talk for the Indonesians in the Philippines and the Indonesians in the USA, had an additional topic such as:

a. The USA

- Homeland and the situation there.

- Current news in the USA

- $\quad$ Living in USA (share a thought, the pleasant and the hardship of living in the USA)

- Funny experiences upon arriving in the USA for the first time.

- New/ alternative places to live (where one can find job easily)

- Shopping (where to find cheap and branded stuff) 
- Indonesian food (Good Indonesian or Oriental Restaurant nearby)

b. The Philippines

- Homeland and the situation there

- Tourist spot to visit

- Educational Information

- The Unique things in the Philippines ( jeepneys, cell phone for texting, etc)

- Indonesian food (good Indonesian or Oriental Spicy Restaurant)

Human beings draw close to one another by their common nature, but habits and customs keep them apart. (Confucian saying)

Part III. What changes of conversational topic has taken place?

\section{A. Indonesian in the USA}

Indonesians who are in USA particularly in LA and New Jersey would eliminate/avoid on the topic on occupation, family and religion (unless they have a very close relationship), particularly whom they stay with, and what they do for a living.

The researcher found out that there were three major things that affect their way of communication, and interaction among the Indonesians whom they met for the first time. And they would eliminate the topic mentioned as for the reason of:

First, their culture has changed, but not completely. They have a feeling of homelessness, where one feels neither bound firmly to one's native culture nor fully adapted to the second culture. Lambert's (1967) termed it anomie. I can say that they have lost their "real" self identity. This is so, because their present lives, working status/ situation and some other aspect of life is no longer the same (mostly lower working status) as to, compare it with, in their motherland. These changes interfere 
them from revealing their present or "real" identity. This situation, then, creates a common understanding, feeling, and act (new cultural practice) amongst Indonesians that is so different with the common practice back in their own country. Therefore, Indonesians thought and talk differ with different cultural setting or environment.

Secondly it is because of the prestige. They were afraid of being gossiped, most of them came in a tourist visa and would like to settle in the state. So they don't have working permit but they needed money for their living, so they are willing to work on anything, which is not of their skill of proficiency. It is difficult for them to find a good position/job at their level due to no working permit. A lot of businessman and businesswomen who had good position in the homeland were not having the same position in the state because of no working permit. So they don't want to be asked about their occupation, since it hurt them or they feel bad and afraid of being gossiped. Although there are others who had a good job/position would rather avoid talking it in specific because many of their friends had a lower working level than them. And they would feel at ease, and worried that they may think that they're showing off because of their good job/position.

The last would be for security sake. They wouldn't reveal their present status, afraid that it might trigger social jealousy. Several cases had happened, that those who are jealous or had conflict at work and those who are with 'green card holder' and had a lower job would report them to the immigration (especially if that person had no working permit). So the topic on occupation was always avoided especially during the gathering together(crowd) but they would talk in 2-3 persons only. This happened to those Indonesians especially who live in Laguna, Loma Linda and Everett Washington. April, 2001 in Everett Washington two companies were inspected from the immigration office and they found and deport all the illegal workers and took them by busses and deport them to their own homeland. So it's a big issues now among the Indonesians who had no working permit to keep their mouth shut. And this is not only happened to the Indonesian but also to other nationalities. They also would avoid on the topic on family particularly whom and where they live for security reason.

\section{B. Indonesian in the Philippines}

The Indonesian who are in the Philippines which is composed mainly of students who are studying in various discipline, still maintain the same topic that we 
have in the motherland/homeland. It is because we share a similar culture (with the Filipino, /the ASEAN culture). And furthermore, we are Asian by race. We share the same tropical climate, season, main food (rice), fruits, etc. The topic remained the same except that there's an expansion/elaboration on the occupation that was being replaced by the university or educational information. Why, because most of the Indonesian in the Philippines are students. So the topic was more on which university are you in and what course, level, semester are you now, etc. And then follow by occupation. Where do you work in Indonesia? There is no hidden status. In fact they exchange address and giving information on the working atmosphere back in the homeland. Moreover some invited friends to join them working in their company/ places in the future (when they returned to Indonesia). Most of the Indonesian in the Philippines are very transparent of their present status because we are all students and realized that as we returned to the homeland the status would be change. And mostly it will go to a higher status due to the additional education obtained. Another interesting behavior the researcher found out that there are some who feel inferior to those who are studying in the recognized university in the Philippines. They feel a little inferior, for example upon talking to UP(University of the Philippines) students if they're from other university which is not well known in the Philippines. But if they are talking to other they don't have the feeling of inferior.

These findings are supported by Samovar et al. 1998/2007 that Cultures are dynamic systems that do not exist in a vacuum, so they are subject to change. Change through contact is another example of how communication and culture are alike. Communication is not static, but rather is dynamic and constantly changing.

\section{Conclusion}

Culture varies, from country to country. As culture refers to the distinctive patterns of thought, action, and value that characterize the members of a society or social group. In social anthropology, the culture relates to arrangements of belief and custom through which social relations are expressed; in ethno-science, culture refers to the set of standards for behavior considered authoritative within a society; and in symbolic studies, culture is a system of meanings though which social life is interpreted (Winthrop, 1991).

These means by which a community communicates........ a commonly agreed-upon set of meanings in interaction with one another.(Steele,1990). 
Dr. P. Covar, in Anthro. 270 class said that" to know ones culture is to know /understands its language". Therefore, language and culture are interwoven.

Language is a part of culture, and culture is a part of language that could not be separated. Dr. M.R. Otero in the International Conference on Teacher Education2001 and EDL 321 mention about the "grammar of culture" where a community who has their own culture may shape the way they pronounce a word and that the culture affect they way they utter it.

In teaching a "Foreign" language we need to be sensitive to the fragility of students by using techniques that promote cultural understanding. In general these various cultures provide a context in which in particular strategies of teaching are developed, sustained and preferred over time. In the same way, the teaching strategies of English/ TEFL (Teaching English as a Foreign Language) teachers evolve differently from those of mathematics teachers, and so on.

And don't forget that teacher is a part of work culture.

Culture is the medium evolved by humans to survive. Nothing in our live is free from cultural influences. It is the keystone in civilization's arch and is the medium through which all life's events must flow. Edward T. Hall.

References

1. Bates and Plog ,1990, p.434 in Samovar et al,1998

2. Cooler Robert 1. 1998 Language Planning and Social Change. Wadsworth Publishing company.

3. Dr. Francisco Sionil Jose (2001) (National Artist for Literature) 'First International Conference and $40^{\text {th }}$ Annual Convention on Language Education' at Manila Midtown Hotel, April 25-27, 2001

4. Gudykunst and Y.Y. Kim, 1992. Communicating With Strangers: An Approach to Intercultural Communication, Second Edition (New York, Mc Graw Hill) p.215. 
5. Hoebel and frost in Samovar et al. 1998

6. Hoebel E.A. and Frost,E,L . Cultural and Social Anthropology, New Delhi Tata McGraw Hill Publishing Company Ltd

7. Nada in samovar et al 1998 .

8. Samovar, Larry A., Richard E. Porter and Lisa A. Stefani,1998.

Communication Between Cultures. Third edition, Wadsworth Publishing company.

9. Samovar, Larry A., Richard E. Porter and Lisa A. Stefani,2007.

Communication Between Cultures. Third edition, Seventh printing. Wadsworth Publishing company. 